\title{
The Research on Influence Factors of Customer Loyalty in C2C Mode
}

\author{
Wu Zhihong \\ School of Economic and Management \\ Shengyang Aerospace University \\ Shengyang, China \\ Wuzh@sau.edu.cn
}

\author{
Wang Qingjun \\ School of Economic and Management \\ Shengyang Aerospace University \\ Shengyang, China \\ 32582669@qq.com
}

\begin{abstract}
Twenty-first centuries is an age with high development of information. With the development of network technology and electronic commerce, market competition is aggravating. Traditional and materialized marketing pattern in society is undergoing profound changes, and network marketing has become an important marketing mode. C2C electronic commerce has become one of the most important shopping ways in our daily life. But due to the particularity of online shopping environment and various existing problems, it' $s$ more difficult if the businesses want build customer loyalty on business than physical environment, and its importance is higher than physical environment. So if the businesses want to maintain the advantage in fierce market competition and maintain longterm and stable development, they must pay attention to customer loyalty.
\end{abstract}

Keywords-network marketing; C2C; customer loyalty; ecommerce

\section{INTRODUCTION}

In recent years, with the development of network technology, electronic commerce has made a rapid popularization in the global scope. It has brought unexpected changes to people's life. E-commerce has not only changed the mode of business operation, but also changed people's consumption habits and shopping behavior and the way people thinking. In China, ecommerce is rapidly affecting a lot of people's way of life. As gradual improvement of the mode of payment, logistics system, credit evaluation and other facilities, online shopping has been gradually accepted and recognized by users, which also makes more and more Internet users be interested in online shopping.

\section{E-COMMERCE CONDITION OF INTERNET UNDER C2C MODE}

According to the thirty-first "Chinese Internet Development Statistics Report" released in January 15, 2013 in Beijing by Chinese Internet Network Information Center (CNNIC), as of the end of Dec.2012, China's Internet users reached 0.564 billion, Internet penetration rate is $42.1 \%$. The online shopping users have reached 0.242 billion, and the online shopping utilization rate increased to $42.9 \%$. Compared with 2011 , online shopping users increase 48.07 million, with $24.8 \%$ growth rate. China Internet Network Information Center (CNNIC) released the thirty-second " Chinese Internet Development Statistics Report ", which indicating that as of the end of June 2013,
China's online shopping users reached 0.271 billion, online shopping utilization rate increased to $45.9 \%$. Compared with the end of Dec.2012, in the first half of 2013, Internet users increased 28.89 million, with semi annual growth rate of $11.9 \%$. The data shows that China's online shopping has taken a very large market share and supplemented the traditional market without the spatial and geographical constraints.

According to the types of transaction subjects, international e-commerce business model structure is mainly divided into three categories: $\mathrm{B} 2 \mathrm{~B}, \mathrm{~B} 2 \mathrm{C}$ and $\mathrm{C} 2 \mathrm{C}$. $\mathrm{B} 2 \mathrm{C}$ and $\mathrm{C} 2 \mathrm{C}$ are the two modes of online shopping chose by individual consumers. From the aspect of consumers selecting online shopping platforms, $\mathrm{C} 2 \mathrm{C}$ platform is still the first choice of consumer online shopping. Today, the online shopping market under $\mathrm{C} 2 \mathrm{C}$ mode is developing vigorously. With Internet users increasing continuously, the market continue to expand, the online shopping market competition becomes fiercer. In the new market environment, if the businesses want to obtain the competitive advantage, access to long-term development, they must secure customer loyalty.

\section{CUSTOMER LOYALTY CLASSIFICATION UNDER C2C MODE}

Customer loyalty classification can be divided into the following types now. The first type can be distinguished with two dimensions, that is, the strength of attitude tendency and behavior approach. The most representative is Griffin classification method. Griffin divided customer loyalty into 4 states according to their frequency of repeated purchasing and positive attitude. See Fig.1.

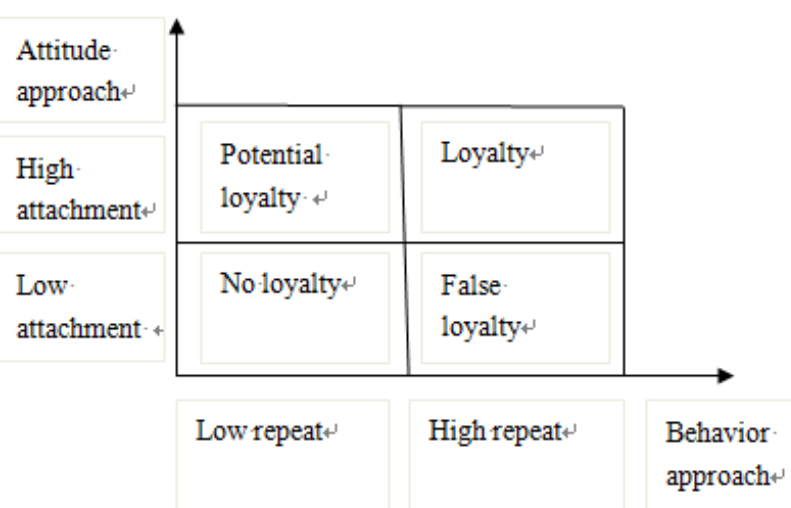

Figure 1. Matrix of customer loyalty types (Griffin, 1995) 
Loyalty. High unification of customer purchasing attitude and behavior can bring long-term value for businesses.

Potential loyalty. Customers often represent the features of low attachment and low repeat purchasing. But from the aspect of emotion, these customers are more likely to continuously buy the products and service, only some factors limiting their behavior.

False loyalty. It means that the customers have low attitude approach but represent to buy continuously in behavior. The customers' false loyalty is affected by some factors. For example, discount leads to price dropping.

No loyalty. Low attitude and low repeat buying indicate that these customers are lack of loyalty. They have no business relationship with these companies for a long time.

Brown and Gremler divided customer loyalty into 3 different levels from another view: behavior loyalty, emotion loyalty and intention loyalty. Oliver divided customer loyalty into 4 levels: cognition loyalty, emotion loyalty, intention loyalty and behavior loyalty, shown as Fig.2:

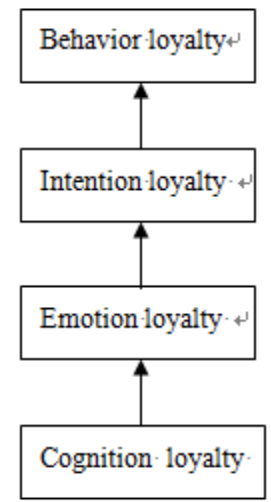

Figure 2. Customer loyalty levels (Oliver, 1999)

\section{STUdy OF C2C CUSTOMER LOYALTY INFLUENCE FACTORS}

The previous researches show that the most of current domestic and foreign customer loyalty influence factors research focus on electronic commerce, but much less under $\mathrm{C} 2 \mathrm{C}$ mode. After the literature review, the author thinks that: the previous researches of customer loyalty influencing factors mainly focus on customer satisfaction, customer value and customer trust, but pay less attention to the service quality and switching cost. Many scholars gave corresponding explanations for the relationship between these factors and customer loyalty from various aspects. Based on these analyses, the author thinks, service quality can indirectly influence customer loyalty through customer satisfaction and customer value, but switching costs and customer satisfaction, customer value, customer trust can directly influence customer loyalty.

\section{MUTUAL RELATION BETWEEN CUSTOMER LOYALTY AND INFLUENCE FACTORS UNDER C2C MODE}

\section{A. The relationship between customer satisfaction and customer loyalty under C2C mode}

There are countless ties between customer loyalty and customer satisfaction. Generally speaking, customer loyalty is established on the basis of customer satisfaction. The customers would be satisfied only when they think that the products and services meet their needs and have very high evaluation for consumer experience overall quality, and then they will become loyal customers. Many studies have shown customer satisfaction has direct effect on customer loyalty, but high customer loyalty can only be achieved with high customer satisfaction.

\section{B. The relationship between customer value and customer loyalty under C2C mode}

The core of customer value is a trade-off of gains and profits perceived by the customer. Many businesses are trying to add value, but if customers do not feel they obtain the value, their efforts can't get the customer loyalty in return. In $\mathrm{C} 2 \mathrm{C}$ mode, the website and seller can provide the customer with value, including: convenience of shopping process and operation interface, transaction security, good reputation and image of the website, personalized service, price advantage, quality of goods, shop credit etc.

\section{The relationship between customer trust and customer loyalty under $\mathrm{C} 2 \mathrm{C}$ mode}

For current online shopping environment, the consumer could not touch the real commodity, and if consumers want to know the quality and information of the goods, they can only browse the description and image information of online merchants, which highlight the network trust problem. When customers buy in the first time, they often find related sellers through clicking the links of their favorable pictures; if the previous shopping experience makes the customer satisfied, establishing certain trust relationship between customer and online shops, which belongs to cognitive trust. Subsequently, customers buy goods in the $\mathrm{C} 2 \mathrm{C}$ online shop for several times. If the commodity information is true, shopping experience is smooth and pleasant, the quality is in line with standards, the customer will not only be satisfied, also give emotional trust on Web sites.

\section{The relationship between service quality and customer loyalty under C2C mode}

In $\mathrm{C} 2 \mathrm{C}$ e-commerce platform, sellers' service quality and websites' service quality will directly affect buyers' shopping experience, and influence the customer satisfaction and customer value further. The service provided by sellers and websites can be mainly attributed to product pictures and data, earnest evaluation for buyers and after-sales service, delivery service of logistics companies, product quality and quantity released shops, simplicity of website design, convenience of operation and transaction security of payment services, online marketing supporting service, service recovery measures and some entertainment services. Among them, online marketing services are provided to the shop sellers by the $\mathrm{C} 2 \mathrm{C}$ 
website. Shop sellers can personalize services according to their own needs. The shop sellers decide whether to adopt relevant marketing tools and corresponding promotional activities.

\section{E. The relationship between customer switching cost and customer loyalty under $\mathrm{C} 2 \mathrm{C}$ mode}

In the traditional mode, switching cost refers to the obstacle and cost for a customer changing the business, which is the sum of all costs paid for business replacement by customers. If a customer changes from a seller to another seller, he will lose a lot of time, effort, money, relationships and feelings, so even if they are not completely satisfied with current business, they will think thrice before acting, and not easily switch to buy. Switching cost is a buffer to prevent customer relationship retrogression, so increasing switching cost is favored to establish and maintain customer loyalty. But in the $\mathrm{C} 2 \mathrm{C}$ mode, due to the convenience of network, it can provide a lot of information for customers, which creates great changes in the transaction environment and process.

\section{THE STRATEGY TO PROMOTE CUSTOMER LOYALTY IN C2C E-COMMERCE MODE}

The author thinks that it can be considered from website and online seller to promote customer loyalty.

\section{A. It will follow the points listed below for the strategy} to promote customer loyalty from $\mathrm{C} 2 \mathrm{C}$ website level

Shape good C2C website image, make website brand marketing well, and promote website credibility and popularity.

Concise design, convenient operation interface, which should have clear layout and be simple.

Provide effective and diversified online marketing services, using a variety of tools, help rich online marketing activities, to improve the shop marketing efficiency, such as pictures and video processing tools, customer service training services, logistics and warehousing services, shop operation agent tools; it also includes Taobao train, flourishing shop, shop promotions, shop promotion, data processing tools and market research tools, up to several hundred tools, specifically for online shop marketing and promotional services.

Add entertainment, personalized services. There are too many online shopping customers, with complex situation and different demands, showing a wide selection, powerful selection right features. The personalized service can make customers find a shopping program meeting their own characteristics and requirements.

Improve the service recovery measures. Because virtual online service does not have entity environment, customers have more concern on shopping risk. At the same time, once the online shop seller process after-sales service improperly, the customer will attribute to the website system, so $\mathrm{C} 2 \mathrm{C}$ website must establish the system that can constrain shop sellers for service recovery and after-sales service system to guarantee the customers' rights and interests, and enhance customers' confidence for shopping platform.

To ensure security of customers' property, payment and enhance customer trust by creating a secure financial payment security measures, establish the third party payment platform, security real name authentication, online reputation rating threshold and other methods.

\section{B. Promote customer loyalty from $\mathrm{C} 2 \mathrm{C}$ online businesses, including following aspects}

Improve the service quality through the whole transaction process. Train service staff in previous to make sure they are familiar with the goods, business process, know the customers' needs, make timely reply and able to provide effective purchasing advice. After transaction completed, there are specific staff processing the evaluations carefully, collecting the feedback information, improving after-sales speed and quality. Provide good after-sale service, striving to make customers satisfied.

Learn about the customer, establish customer files and membership system, to meet customers' requirements and improve customer satisfaction.

Ensure the commodity quantity and updating rate. In online shopping, customers having wide range of choice and strong selection power; to maintain the attractiveness to customers and improve customer loyalty, the quantity of the goods and updating the goods constantly must be ensured, so that customers can see rich variety of goods and find their favored goods every time.

Ensure the commodity quality and customers' receiving quality. The promise for customer in transaction negotiation must be fulfilled. If the goods have quality problems, the shop must be able to provide consumers with a reasonable return service, effectively protect the rights and interests of consumers. At the same time, satisfy customers' distribution requirements as much as possible, select delivery service from several logistics companies, no delay, and with high efficiency. Ensure reducing customers' delivery time, and delivery quality.

Make price strategy of shop's goods, and adjust regularly to make sure the price attractive.

Goods information and quality mast be ensured and attractive. Goods picture must be beautiful after processing, not only complying with the reality but also be attractive. Attention that the picture and information must be true Due to the vitality of internet, if the picture and information are much different with the real goods, it will affect customer's perception.

Be skilled in using $\mathrm{C} 2 \mathrm{C}$ marketing tools. Make promotion methods according to their actual conditions, attract customers to buy. For example, anniversary price cutting, period promotion, holiday promotion, outdated goods discount and so on.

\section{CONCLUSION}

China has already entered the development of ecommerce era. Customer loyalty is the security to win in fierce competition and obtain long-term interests.

Harvard University Professor Ted Leavitt said in "Marketing Myopia": "no growing enterprises, there are only the customer's needs, but the customer needs time to change". Indeed, today's customers are no longer allowed controlled by the company. The customers have power to control; they have "money votes", which are coveted by many companies. In such an environment, the final winner is a company who understands the establishment of "faithful partnership" with customers. "Customer loyalty" 
has become a focus of Internet merchants. How to improve customer loyalty is the pursuing goal of numerous network businesses. Therefore, particularly for the sellers of online transactions in $\mathrm{C} 2 \mathrm{C}$ mode, customer loyalty is more important. They identify effective strategies to improve customer loyalty through analyzing the influence factors of customer loyalty to get more profit. According to theoretical analysis and survey analysis, the paper discusses the influencing factors of customer loyalty under $\mathrm{C} 2 \mathrm{C}$ mode and gives feasible suggestions in $\mathrm{C} 2 \mathrm{C}$ ecommerce mode, which will be of great reference value to the later research or network business, making the relationship between customers and sellers reach unknown level.

\section{REFERENCES}

[1] Yan Sheng, Li Xiaoling. Empirical Analysis of Customer Loyalty Influence Factors In the Network Marketing [J]. Chinese Information Management, 2010, (6):112-114.

[2] Reporter Gao Sha. Customer Loyalty from "Function" and "Emotion" [N]. Workers Daily, 2013-7-20 (18).

[3] Fu Chao, Liu Yingzi. Cognitive Error Region of Customer Loyalty [J]. Public Enterprise Management,2012, (4):46-48.

[4] Li Ji, Zhao Zhanbo, Xie Yi. Customer Relationship Management [M]. Beijing: Chemical Industry Press, 2011.65-72.

[5] Yi Wen. Magic to Improve Customer Loyalty [N]. Financial Times, 2011-5-26 (5).

[6] Ma Qingxue. Strategy of Network Marketing Enterprises to Cultivate Consumer Loyalty [J]. Enterprise Observation, 2010, (9):116-118.

[7] Yang Desheng Need "Customer Satisfaction" But Need More "Customer Loyalty" [N]. Chinese Post, 2013-4-28 (2).

[8] Su Lizhao, Cui Yanwu, Chen Ting. Analysis and Empirical Research on Network Consumer Behavior Influencing Factor [J]. Systems Engineering, 2013, (2):26-34.

[9] Zhou Huanhuai. Thinking of How to Develop Customer Loyalty of Electronic Commerce Enterprise [J]. Business Research (2013, 14):205-206.

[10] Frederic F Kerr Lai. Loyalty Rule [M]. Beijing: CITIC Publishing House, 2012.75-86.

[11] Ronald S Swift. Customer Relationship Management [M]. Beijing: Chinese Economic Publishing House, 2012.48-52.

[12] Chen Mingliang. Empirical Research of Customer Repurchase Intention Decisive Factors [J]. Science Research Management 2013, (1):110-115.

[13] Han Jingguan, Wei Fuxiang. Study of Customer Satisfaction and Customer Loyalty Relationship [J]. Nankai Business Review, 2011, (6):25-40.

[14] Li Guifang. How to Construct Customer Pyramid [J]. Commercial Age Theory, 2014, (35):23-34.

[15] Cha Jinxiang. Study on the Relationship between B2c ECommerce Customer Value And Customer Loyalty [D]. Zhejiang: Zhejiang University, 2014

[16] Gefen,D.\& Straub, D.W.Consumer trust in B2C e-Commerce and the importance of social Presence: experiments in e-Products and e-Services[J].The International Journal of Management Science, 2014,32(6):407- 424.

[17] JONES H. Contact management and customer loyalty[J].Journal of Financial Services Marketing,2013,8(3):71 -78. 